\title{
DAMPAK PENERAPAN METODE PENGHAPUSAN PIUTANG TAK TERTAGIH TERHADAP PENDAPATAN RUMAH SAKIT UMUM DAERAH (RSUD) SEKAYU KABUPATEN MUSI BANYUASIN
}

\author{
Oleh \\ Masri Ermawijaya \\ STIE Rahmaniyah Sekayu \\ Email : Masriermawijya60@gmail.com
}

\begin{abstract}
Penelitian ini bertujuan mengetahui penerapan metode penghapusan piutang tak tertagih terhadap pendapatan Rumah Sakit Umum Sekayu. Metode dalam penelitian ini menggunakan metode deskriptif kualitatif. Data dalam penelitian ini adalah data primer dan data sekunder. Data primer adalah data dari hasil wawancara. Data sekunder adalah data tentang piutang dan pendapatan RSUD Sekayu. Hasil penelitian ini dianalisis dari sudut penyebab piutang tak tertagih adalah karena penagihan piutang (klaim) kepada perusahaan seringkali mengalami keterlambatan dan jumlah piutang yang ditagih kepada perusahaan dibayar tidak sesuai dengan jumlah tagihan, sementara dokter dan tenaga medis lainnya menuntut pembayaran jasa dilakukan secara tepat waktu. Namun dari sudutManajemen RSUD Sekayu telah memperlakukan penghapusan piutang tak tertagih dengan menggunakan metode penghapusan tidak langsungcadangan,sebagai akibat dari penerapan metode ini nilai piutang yang disajikan di neraca tidak menunjukkan nilai yang sebenarnya, namun dalam kenyataannya RSUD hanya mengestiamsi saja piutang tak tertagih dan tidak dikurangkan dari cash flow RSUD Sekayu, sehingga akan berdampak pada surplus pendapatan yang di peroleh. Serta manajemen RSUD Sekayu belum melakukan pengurangan ini karena keberatankinerja manajemen dianggap kurang baik.Upaya yang harus dilakukan oleh manajemen RSUD Sekayu disarankan adalah untuk secara bertahap menghapuskan piutang yang tidak dapat direalisasikan setiap tahun sehingga secara akuntansi dan kebijakan manajamen Rumah Sakit dapat diterapkan secara bersama dan tidak melanggar ketentuan akuntansi yang berlaku.
\end{abstract}

Kata kunci: Metode Penghapusan Piutang, Piutang Tak Tertagih dan Pendapatan

\section{I.PENDAHULUAN}

\subsection{Latar Belakang Penelitian}

Sumber pembiayaan rumah sakit yang berstatus milik pemerintah berasal dari anggaran pemerintah dan iuran masyarakat pengguna jasa, sedangkan untuk organisasi kesehatan atau rumah sakit yang berstatus milik swasta sumber 
pembiayaannya berasal dari alokasi dana yayasan/pemilik/sumbangan lain dan masyarakat pengguna jasanya. Pola pembiayaan, berupa :

1. Membayar sendiri (out of pocket)

2. Ditanggung oleh Asuransi Kesehatan Pemerintah

3. Ditanggung oleh Asuransi Kesehatan Swasta

4. Ditanggung oleh Perusahaan

Sumber pendapatan rumah sakit yang terbesar adalah pendapatan dari pengguna jasa yaitu pasien berupa piutang pasien ((patient account receivable), maka dari itu pengelolaan atas piutang menjadi sangat penting dalam perolehan pendapatan rumah sakit Karena itu pengelolaan piutang dengan pihak penjamin (Jaminan kesehatan) merupakan hal yang penting dalam operasional rumah sakit.

Rumah SakitUmum Daerah (RSUD) Sekayu Kabupaten Musi Banyuasin merupakan salah satu instansi yang berada di bawah koordinasi Pemerintahan Daerah Kabupaten Musi Banyuasin dengan tipe Bdengan tipe penjamin yang berbeda-beda yaitu pasien bayar sendiri (mandiri), pasien jaminan perusahaan (jaminan asuransi swasta), pasien Askessos, BPJS pasien Kartu Indonesia Sehat (KIS) dan pasien Jamkesmas. Pasien tersebut dirawat di ruang rawat inap yang keseluruhannya memiliki kapasitas 166 tempat tidur yang terbagi ke dalam beberapa kelas.

Berdasarkan survey awal, berikut ini disajikan data piutang tak tertagih RSUD Sekayu Tahun 2016 sampai dengan 2018 dapat terlihat pada tabel dibawah ini:

Tabel 1

Piutang Tak Tertagih

RSUD Sekayu

Tahun 2016 sampai dengan 2018

(Dalam Rupiah)

\begin{tabular}{|l|r|r|r|}
\hline \multirow{2}{*}{ Uraian } & \multicolumn{3}{c|}{ Tahun } \\
\cline { 2 - 4 } & \multicolumn{1}{c|}{2016} & \multicolumn{1}{c|}{2017} & \multicolumn{1}{c|}{2018} \\
\hline Pasien Perusahaan & 665.342 .156 & 612.308 .148 & 753.139 .023 \\
\hline Jamkesda & 4.583 .985 .074 & 2.147 .856 .472 & 2.104 .899 .343 \\
\hline Jamkesmas & 500.637 .258 & 983.423 .451 & 1.376 .792 .831 \\
\hline Jamsoskes & 2.290 .700 .584 & 2.424 .696 .510 & 2.036 .745 .068 \\
\hline BPJS Kesehatan & 804.458 .082 & 602.109 .372 & 806.826 .559 \\
\hline Total Piutang & 8.845 .123 .154 & 6.770 .393 .953 & 7.078 .402 .823 \\
\hline \% Peningkatan (Penurunan) & - & $(23,46 \%)$ & $4,55 \%$ \\
\hline
\end{tabular}

Sumber: RSUD Sekayu, 2018, data diolah 
Berdasarkan data pada Tabel 1, bahwa jumlah piutang tak tertagih pada RSUD Sekayu dari Tahun 2016 sampai dengan 2018 mengalami fluktuasi dengan jumlah yang berbeda. Hasil hipotesa sementara penulis menyatakan besarnya jumlah piutang yang tak tertagih/menunggak karena penagihan piutang (klaim) kepada perusahaan seringkali mengalami keterlambatan dan seringkali piutang yang ditagih kepada perusahaan dibayar tidak sesuai dengan tagihan. Masalah yang sering timbul akibat keterlambatan penagihan piutang ini adalah mengakibatkan menghambat cash flow keuangan rumah sakit, sementara dokter dan tenaga medis lainnya menuntut pembayaran jasa mereka dilakukan secara tepat waktu dan dalam proses penagihan piutang (klaim) piutang baik melalui BPJS maupun pihak ketiga lainnya yang selalu mengalami keterlambatan.Berikut ini disajikan pendapatan RSUD Sekayu pada Tabel 2.

Tabel 2

Pendapatan RSUD Sekayu

Kabupaten Musi Banyuasin

Tahun 2016-2018

(Dalam Rupiah)

\begin{tabular}{|c|r|r|r|}
\hline \multirow{2}{*}{ Uraian } & \multicolumn{3}{|c|}{ Tahun } \\
\cline { 2 - 4 } & \multicolumn{1}{|c|}{$\mathbf{2 0 1 6}$} & \multicolumn{1}{c|}{$\mathbf{2 0 1 7}$} & \multicolumn{1}{c|}{$\mathbf{2 0 1 8}$} \\
\hline Pendapatan: & & & \\
\hline Pelayanan Kesehatan & & & \\
\hline Rawat Jalan & 2.116 .071 .906 & 1.723 .512 .740 & 1.897 .925 .454 \\
\hline Rawat Inap & 50.710 .087 .003 & 41.866 .264 .950 & 45.641 .939 .825 \\
\hline Pendapatan Lain-lain & & & \\
\hline Diklat & 36.495 .000 & 29.724 .698 & 32.732 .720 \\
\hline Sewa & 27.000 .000 & 21.991 .145 & 24.216 .562 \\
\hline Jasa Giro & 78.183 .099 & 63.679 .106 & 70.123 .181 \\
\hline Parkir & 68.955 .000 & 56.162 .941 & 61.846 .410 \\
\hline Total Pendapatan & 53.036 .792 .008 & 43.761 .335 .579 & 47.721 .287 .236 \\
\hline Beban Operasional & & & \\
\hline Biaya Operasional & 37.364 .419 .970 & 30.432 .828 .699 & 33.512 .511 .328 \\
\hline Biaya Umum dan Adminitrasi & 12.171 .042 .140 & 9.913 .153 .766 & 10.916 .325 .957 \\
\hline Total Biaya Operasional & 49.535 .462 .110 & 40.345 .982 .466 & 44.428 .837 .285 \\
\hline Surplus (Defisit) Pos Keuangan & 3.501 .329 .898 & 2.851 .787 .157 & 3.140 .376 .807 \\
\hline Biaya Non Operaional & 3.362 .532 .613 & 2.738 .738 .594 & 3.015 .888 .173 \\
\hline Surplus (Defisit) Tahun Berjalan & 138.797 .285 & 113.048 .563 & 124.488 .633 \\
\hline
\end{tabular}

Sumber: RSUD Sekayu Kabupaten Musi Banyuasin, 2018, data diolah 
Berdasarkan data pada Tabel 2 di atas, maka dapat dijelakan bahwa pendapatan RSUD Sekayu mengalami fluktuasi. RSUD Sekayu belum memperlakukan piutang tak tertagih dengan akun kerugian piutang setiap tahun sebagai pengurang dari pendapatan RSUD Sekayu. Berdasarkan ketentuan Peraturan Gubernur nomor 9 tahun 2014 seharusnya RSUD Sekayu sudah menerapkan metode penghapusan piutang secara tidak langsung atau cadangandalam menghapus piutang tak tertagih dalam laporan keuangannya.

\subsection{Rumusan Masalah}

Berdasarkan latar belakang di atas, maka permasalahan yang akan dibahas dalam penelitian ini adalah

1. Metode penghapusan piutang Rumah Sakit Umum Daerah (RSUD) Sekayu Kabupaten Musi Banyuasin belum sepenuhnya diterapkan.

2. Dampak penerapan metode penghapusan piutang tak tertagih terhadap perolehan pendapatan pada Rumah Sakit Umum Daerah (RSUD) Sekayu Kabupaten Musi Banyuasin.

\subsection{Tujuan Penelitian}

Adapuntujuandaripenelitianiniadalahuntuk mengetahuipenerapan metode penghapusan piutang tak tertagih dan dampaknya terhadap pendapatanRumah Sakit Umum Daerah (RSUD) Sekayu Kabupaten Musi Banyuasin.

\section{LANDASAN TEORI}

\subsection{Konsep Piutang}

\subsubsection{Pengertian Piutang}

Piutang merupakan komponen aktiva lancar yang penting dalam aktivitas ekonomi suatu perusahaan karena merupakan aset lancar perusahaan yang paling besar setelah kas. Piutang ini timbul karena adanya penjualan barang atau jasa secara kredit, atau bisa juga melalui pemberian pinjaman.. Setiawan (2010:199), mengatakan piutang adalah segala bentuk tagihan atau klaim perusahaan kepada pihak lain yang pelunasannya dapat dilakukan dalam bentuk uang, barang maupun jasa, sedangkan Horne (2014:258), mengatakan piutang meliputi jumlah uang 
yang dipinjam dari perusahaan oleh pelanggan yang telah membeli barang atau telah memakai jasa secara kredit.

Piutang dapat timbul dari berbagai macam sumber, tetapi jumlah yang terbesar biasanya timbul dari penjualan barang atau jasa. Berdasarkan Pernyataan Standar Akuntansi Keuangan Nomor 1 (2009:451) mengemukakan bahwa menurut sumber terjadinya, piutang digolongkan ke dalam dua kategori yaitu: piutang usaha dan piutang lain-lain. Piutang usaha timbul karena penjualan produk atau jasa dalam rangka kegiatan normal usaha, sementara piutang yang timbul di luar kegiatan normal usaha digolongkan sebagai piutang lain-lain.

\subsubsection{Jenis Piutang}

Menurut Warren (2008:356), jenis-jenis piutang terdiri dari piutang dagang, piutang wesel dan piutang lain-lain, yaitu :

1. Piutang dagang, adalah piutang yang timbul dari transaksi penjualan barang atau jasa secara kredit dalam kegiatan normal perusahaan.

2. Piutang wesel, adalah janji tertulis yang tidak bersyarat dari satu pihak kepada pihak lain untuk membayar sejumlah uang tertentu pada tanggal tertentu dimasa yang akan datang.

3. Piutang Lain-lain, adalah merupakan kategori macam-macam tagihan yang tidak termasuk dalam piutang dagang dan piutang wesel. Yang termasuk didalamnya piutang kepada karyawan perusahaan, direksi perusahaan dan piutang kepada cabang-cabang perusahaan.

\subsubsection{Penilaian Piutang}

Berdasarkan Pernyataan Standar Akuntansi Keuangan (2009:36), penilaian piutang di neraca dinyatakan sebesar bruto tagihan dikurangi dengan taksiran jumlah yang tidak dapat ditagih.

\subsubsection{PenentuanKerugianPiutang}

Menurut Haryono (2014:59), ada 2 (dua) jumlah piutang yang diperkirakan tidak tertagih telah ditetapkan oleh manajemen.

\section{PersentasedariPenjualan}

Manajemenmenetapkan suatu persentase antara jumlah kredit dengan taksiran kerugian yang mungkin diderita karena adanya piutang tak tertagih. 
2. PersentasedariPiutang

Manajemen menetapkan persentase tertentu antara total piutang dengan jumlah adanya piutang tak tertagih, dengan cara menyusun daftar umur piutang debitur berdasarkan masa lewat waktu dari jatuh tempo piutang dan menetapkan presentase taksiran kerugian piutang yang didasarkan pada kebijakan dan pengalaman masa lalu terhadap total masing-masing kelompok umur piutang.

\subsection{Konsep Piutang Tak Tertagih}

\subsubsection{Pengertian Piutang Tak Tertagih}

Piutang tak tertagih yang dikemukakan oleh Haryono (2014:65), adalah piutang yang dapat menimbulkan kerugian karena debitur tidak mau atau tidak mampu melaksanakan kewajibannya. Menurut Kieso dan Weygandt (2014:420), piutang tak tertagih merupakan kerugian pendapatan yang memerlukan ayat pencatatan yang tepat didalam perkiraan penurunan harta piutang serta penurunan yang berkaitan dalam laba dan ekuitas pemegang saham.

\subsubsection{Faktor Penyebab dan Dampak PiutangTakTertagih}

Menurut Abdul (2012:45), kredit macet atau piutang taktertagih dapat disebabkan oleh beberapa faktor diantaranya:

1. Faktor Internal, yaitu faktor-faktor yang berasal dari pihak kreditur, misalnya kelemahan tahap pemberian kredit yaitu kurang tajamnya analisis kredit dalam menganalisis calon debitur.

2. Faktor Eksternal, yaitu faktor-faktor yang berasal dari pihak debitur, seperti watak debitur, penggunaan kredit yang tidak sesuai posisinya, kondisi ekonomi dan terjadinya bencana alam.

Atmaja (2012:68), menyimpulkan bahwa bagi kredit bermasalah akan berdampak pada daya tahan perusahaan antara lain:

1. Likuiditas merupakan hal yang penting bagi perusahaan karena berhubungan dengan kemampuan perusahaan untuk memenuhi kewajiban jangka pendeknya.

2. Solvabilitas adalah kemampuan perusahaan untuk memenuhi kewajiban jangka panjangnya atau kemampuan perusahaan membayar suatu bank apabila bank tersebut dilikuidasi. 
3. Rentabilitas yaitu kemampuan perusahaan untuk memperolah penghasilan berupa bunga kredit atau perbandingan antara laba usaha dengan modal saham ditambah modal asing untuk menghasilkan laba.

4. Profitabilitas adalah kemampuan perusahaan untuk memperoleh keuntungan, hal ini terlihat pada perhitungan tingkat produktifitasnya yang akan dituangkan dalam rumus ROA jika kredit tidak lancar, maka profitabilitas menjadi kecil.

5. Bonafitas yakni kepercayaan yang diberikan masyarakat kepada suatu bank, hal ini bukanlah masalah yang mudah karena adanya kredit bermasalah dapat merusak citra perusahaan.

\subsection{KonsepManajemenPiutangRumahSakit}

\subsubsection{Jenis-jenisPiutangRumahSakit}

Berdasarkan pedoman akuntansi Rumah Sakit, piutang pada entitas Rumah Sakit (hospital entity) di kelompokkan menjadi :

1. Piutang pelayanan (service receivable), yang dibagi lagi menjadi :
a. Piutang Jaminan Sosial (social security receivables)
b. Piutang Jaminan Perusahaan (company's rance receivables)
c. Piutang Asuransi (insurance recevables)
d. Piutang Jaminan perorangan (individual insurance receivables)
e. Piutang pasien dalam perawatan (patient receivable)

Piutang di atas diakui setelah selesainya pemberian pelayanan kepada pasien kecuali untuk piutang pasien dalam perawatan. Untuk hal ini piutang diakui pada saat jasa telah diberikan.

2. Piutang lain-lain (other receivables)
a. Piutang pegawai/karyawan (employee receivables)
b. Piutang sewa (lease receivables) (ruang/tempat dan fasilitas)

\subsubsection{Dasar adanya ManajemenPiutang}

Menurut Warren (2008:356), penting nya manajemen piutang didasari oleh adanya hal-halberikut:

1. Piutang merupakan bagian dari liquiditas Rumah Sakit

2. Di Amerika Serikat piutang merupakan $45 \%$ dari penerimaan rawat inap 
3. Perlunya merumuskan kebijakan pengelolaan piutang pasien yang lebih mantap

4. Pada sekitar tahun 1985 mulai digalakan asuransi kesehatan, sehingga perlu persiapan menghadapinya

5. Dengan makin meluasnya kartu kredit maka perlu penataan system penagihan.

\subsection{Konsep Metode Penghapusan Piutang}

Menurut Haryono (2014:54), ada 2 (dua) cara untuk melakukan pencatatan kerugian piutang sebagai berikut:

1. Metode Langsung

Metode langsung adalah metode yang diakui dan dicatat ketika debitur sudah tidak mungkin lagi membayar hutang. Metode penghapusan langsung digunakan hanya pada saat piutang benar-benar tidak tertagih sedangkan pada akhir periode tidak perlu dilakukan jurnal penyesuaian, karena piutang yang dihapuskan tersebut belum tentu berasal dari transaksi yang terjadi pada tahun penghapusannya, hal ini karena jumlah piutang yang begitu material, disamping untuk memperkirakan piutang yang tidak dapat ditagih mungkin biayanya lebih besar dari pada piutang itu sendiri.

2. Metode Penghapusan Tidak Langsung atau Cadangan

Metode cadangan digunakan apabila kerugian piutang yang terjadi, cukup besar jumlahnya. 3 (tiga) hal yang berkaitan dengan metode cadangan yaitu :

a. Piutang yang tidak tertagih ditaksir jumlahnya terlebih dahulu, dan diakui sebagai biaya pada periode penjualan.

b. Taksiran kerugian piutang dicatat dengan mendebet kerugian piutang dan mengkredit cadangan kerugian piutang melalui jurnal penyesuaian.

c. Piutang yang benar-benar tidak dapat tertagih. Dicatat dengan debet cadangan kerugian piutang dan kredit piutang dagang pada saat piutang tersebut dihapus dari pembukuan.

Jurnal pencatatan kerugian piutang dengan menggunakan metode cadangan dan metode penghapusan langsung dapat dilihatTabel 3 
Tabel 3

Jurnal Pencatatan Kerugian Piutang dan Cadangan Kerugian Piutang

\begin{tabular}{|c|c|c|}
\hline Metode Cadangan & & Metode Penghapusan Langsung \\
\hline $\begin{array}{l}\text { Pencatatan taksiran kerugian piutar } \\
\text { Kerugian piutang } \\
\text { Cadangan kerugian piutang }\end{array}$ & ng: & Tidak ada jurnal \\
\hline $\begin{array}{l}\text { Pencatatan penghapusan piutang: } \\
\text { Cadangan kerugian piutang } \mathrm{xxx} \\
\text { Piutang dagang }\end{array}$ & $\mathrm{xxx}$ & $\begin{array}{l}\text { Pencatatan penghapusan piutang: } \\
\begin{array}{l}\text { Kerugian piutang } \\
\text { Piutang dagang }\end{array} \quad \mathrm{xxx} \quad \mathrm{xxx}\end{array}$ \\
\hline $\begin{array}{l}\text { Penerimaan kembali piutang } \\
\text { sudah dihapus: } \\
\text { Piutang dagang } \\
\quad \text { Cadangan kerugian piutang } \\
\text { (Untuk mencatat penerimaan kas) }\end{array}$ & yang & $\begin{array}{l}\text { Penerimaan kembali piutang yang } \\
\text { sudah dihapus: } \\
\text { Piutang dagang } \quad \mathrm{xxx} \\
\text { Kerugian piutang } \\
\text { (untuk mencatat penerimaan kas) }\end{array}$ \\
\hline $\begin{array}{l}\text { Kas } \\
\quad \text { Piutang dagang } \\
\text { (menutup akun kerugian piutang) }\end{array}$ & $\mathrm{xxx}$ & $\begin{array}{lll}\text { Kas } & \mathrm{xxx} & \\
\text { Piutang dagang } & & \mathrm{xxx}\end{array}$ \\
\hline $\begin{array}{l}\text { Cadangan kerugian piutang } \mathrm{xxx} \\
\text { Kerugian piutang }\end{array}$ & $\mathrm{xxx}$ & \\
\hline
\end{tabular}

Sumber : Al Haryono Yusuf (2014)

\section{METODOLOGI PENELITIAN}

\subsection{Jenis dan Sumber Data}

Husein (2011: 45), menyatakan jenis dan sumber data penelitian terdiri dari:

a. Data Primer

Data primer adalah data yang diperoleh langsung dari sumber asli (tidak melelui media perantara) data primer dapat berupa opini subjek (orang) secara individual atau kelompok, hasil observasi terhadap suatu benda atau fisik, kejadian atau kegiatan, dan hasil pengujian. Adapun jenis data primer yang digunakan data dari hasil wawancara dengan pihak yang terkait. 
b. Data Sekunder

Data sekunder adalah data yang diperoleh atau dikumpulkan peneliti dari berbagai sumber yang telah ada, biasanya sudah dalam publikasi-publikasi Data sekunder yang digunakan yaitu data tentang keadaan umum perusahaan dan piutang dan pendapatan pada Rumah Sakit Umum Daerah Sekayu Kabupaten Musi Banyuasin.

\subsection{Teknik Pengumpulan Data}

Sugiyono (2010: 132), menyatakan teknik pengumpulan data terdiri dari:

a. Studi Pustaka

Menelaah teori-teori yang bersumber dan buku-buku teks, teori-teori dan literatur, jurnal dan sebagainya untuk mendapatkan landasan teoritis yang berhubungan dengan penelitian.

b. Penelitian Lapangan

Dilakukan dengan cara mengadakan penelitian langsung pada objek penelitian dengan cara sebagai berikut :

1) Wawancara

Yaitu melakukan wawancara atau tanya jawab dengan pihak-pihak terkait yang berhubungan dengan permasalahan yang ada.

2) Dokumentasi

Yaitu mengumpulkan data dengan cara mengalir atau mengambil data-data dari catatan, dokumentasi, administrasi yang sesuai dengan masalah yang diteliti. Data tentang keadaan umum perusahaan dan laporan keuangan pada Rumah Sakit Umum Daerah Sekayu Kabupaten Musi Banyuasin..

\subsection{Metode Penelitian}

Sugiyono (2010:333), Untuk menganalisis data yang telah dikumpulkan, penulis menggunakan deskriptif kualitatif yaitu yang digunakan adalah analisis yang diwujudkan dengan cara menggambarkan kenyataan atau keadaan-keadaan atau suatu objek dalam bentuk uraian kalimat berdasarkan keterangan-keterangan dari pihak-pihak yang berhubungan dengan penelitian ini mengenai dampak penerapan metode penghapusan piutang tak tertagih terhadap pendapatan. Hasil 
Jurnal Ilmiah Akuntansi Rahmaniyah (JIAR)

Vol. 3 No.1, Desember 2019, 50 -67

Ermawijaya

analisis tersebut kemudian diinterpretasikan guna memberikan gambaran yang jelas terhadap permasalahan yang ada.

\section{PEMBAHASAN}

\subsection{Analisis Metode Penghapusan Piutang Tak Tertagih pada RSUD Sekayu}

Kerugian piutang akan relatif mudah apabila terjadinya transaksi piutang dalam periode yang, namun dalam kenyataan kerugian piutang seringkali terjadi tidak dalam periode yang sama. Untuk itu setiap akhir periode manajemen RSUD Sekayu harus melakukan estimasi besarnya piutang yang diperkirakan tidak dapat diterima atau dilunasi.

RSUD Sekayu dalam melakukan penghapusan piutang tak tertagih menggunakan metode penghapusan tidak langsung atau cadangan. Adapun pertimbangan pengakuan piutang tak tertagih pada RSUD Sekayu adalah dengan pertimbangan umur piutang. Piutang tak tertagih diakui apabila piutang tersebut sudah dinyatakan tidak akan tertagih atau kadaluwarsa setelah melampaui jangka waktu 3 tahun terhitung sejak saat terutang.

Metode ini mengasumsikan bahwa dari setiap pendapatan jasa akan dihasilkan piutang usaha dan selanjutnya membuktikan bahwa piutang tertentu ternyata tidak tertagih serta menjadi tidak bernilai. Metode penghapusan tidak langsung menandingkan biaya dengan pendapatan pada periode bersangkutan atau menghasilkan piutang yang ditetapkan pada estimasi nilai yang dapat direalisasi di neraca.

Dalam metode penghapusan piutang secara tidak langsung atau cadangan memiliki kelemahan yaitu :

1. Pada metode penghapusan langsung piutang seringkali dilaporkan pada periode yang berbeda dengan periode berjalan. Kerugian piutang yang seharusnya merupakan beban dalam tahun buku 2016 baru diakui sebagai biaya dalam tahun buku 2017 dan kerugian piutang yang seharusnya merupakan biaya tahun 2017 diakui sebagai biaya pada tahun 2018 demikian seterusnya, akibatnya didalam mengakui adanya kerugian piutang sebagai biaya dapat berakibat terjadinya salah penyajian yang material, terutama 
apabila piutang yang ternyata tidak tertagih cenderung berfluktuasi atau naik turun dari tahun ke tahun, sedangkan hasil pembiayaan relative stabil.

2. Didalam mengakui biaya kerugian piutang akan tercermin dalam laporan laba rugi dan neraca. Dalam metode penghapusan tidak langsung atau cadangan terhadap hasil usaha atau laba rugi (dalam konsdisi tertentu) hanya berpengaruh pada tahun pertama sejak metode diterapkan, maka tidak demikian halnya dengan neraca. Piutang dagang yang disajikan didalam neraca hanya dilaporkan sebesar jumlah nettonya, yang tampak tidak hanya pada akhir tahun pertama tetapi juga dalam tahun-tahun buku berikutnya. Sehingga pada tahun berikutnya berapa jumlah piutang tak tertagih yang dialami oleh RSUD Sekayu tidak muncul lagi, hal ini akan menyulitkan RSUD apabila terjadi transaksi pelunasan oleh pasien terhadap piutang tak tertagih tersebut.

3. Metode penghapusan tidak langsung atau cadangan hanya dianggap tepat apabila kerugian piutang material jumlahnya atau apabila taksiran yang layak menyangkut piutang yang tidak tertagih dibuat pada setiap akhir tahun bukunya. Pada umumnya tidak bisa dibuatnya taksiran yang layak menyangkut piutang yang tidak tertagih juga menunjukkan adanya ketidak pastian yang benar akan kolektibilitas piutang. Dalam kondisi demikian Standar Akuntansi Keuangan (SAK) menyarankan pengakuan pendapatan dilakukan kemudian yaitu setelah terjadinya transaksi penerimaan piutang atau ditunda sampai diperolehnya kepastian akan kolektibilitas piutang.

Dasar yang digunakan RSUD Sekayu untuk menghitung persentase umur piutang adalah peraturan Gubernur Sumatera Selatan No 9 Tahun 2014 tentang Pedoman Pengelolaan Piutang Badan Layanan Umum Daerah, dengan rincian sebagai berikut :

1. Lancar sebesar $0 \%$

2. Menunggak lebih 1-2 tahun sebesar $25 \%$

3. Menunggak lebih 2-3 tahun sebesar $50 \%$

4. Menunggak lebih 3-5 tahun sebesar $75 \%$

5. Menunggak lebih 5 tahun sebesar $100 \%$ 
Jurnal Ilmiah Akuntansi Rahmaniyah (JIAR)

Vol. 3 No.1, Desember 2019, 50-67

\section{Ermawijaya}

Berikut ini disajikan data piutang dan estimasi piutang tak tertagih RSUD Sekayu dengan metode umur piutang yang disusun oleh bagian verifikasi piutang RSUD Sekayu yaitu saudara Mediyansah Yusuf, S.E., dan berdasarkan peraturan Gubernur Sumatera Selatan No 9 Tahun 2014 tentang Pedoman Pengelolaan Piutang Badan Layanan Umum Daerahadalah sebagai berikut: 
Tabel 4

Piutang RSUD Sekayu

Kabupaten Musi Banyuasin

Tahun 2016-2018

(Dalam Rupiah)

\begin{tabular}{|c|c|c|c|c|c|c|c|c|c|c|c|c|}
\hline \multirow{3}{*}{ Uraian } & \multicolumn{12}{|c|}{ Tahun } \\
\hline & \multicolumn{4}{|c|}{2016} & \multicolumn{4}{|c|}{2017} & \multicolumn{4}{|c|}{2018} \\
\hline & Pasien & PiutangTertagih & $\begin{array}{l}\text { Piutang Tak } \\
\text { Tertagih }\end{array}$ & Jumlah & Pasien & PiutangTertagih & $\begin{array}{c}\text { Piutang } \\
\text { TakTertagih }\end{array}$ & Jumlah & Pasien & Piutang Tertagih & $\begin{array}{l}\text { Piutang } \\
\text { TakTertagih }\end{array}$ & Jumlah \\
\hline $\begin{array}{c}\text { Pasien } \\
\text { Perusahaan }\end{array}$ & 1478 & 1.162 .520 .911 & 665.342 .156 & 1.827 .863 .067 & 1429 & 1.069.857.095 & 612.308 .148 & 1.682 .165 .243 & 1.480 & 1.315.924.226 & 753.139 .023 & 2.069.063.249 \\
\hline Jamkesda & 79651 & 8.365 .125 .304 & 4.583.985.074 & 12.949 .110 .378 & 77032 & 3.919.534.692 & 2.147.856.472 & 6.067.391.164 & 86.295 & 3.841.143.998 & 2.104.899.343 & 5.946 .043 .341 \\
\hline Jamkesmas & 3762 & 837.965 .035 & 500.637 .258 & 1.338 .602 .293 & 3638 & 1.646 .051 .016 & 983.423 .451 & 2.629 .474 .467 & 2.615 & 2.304.471.423 & 1.376 .792 .831 & 3.681 .264 .254 \\
\hline Jamsoskes & 4831 & 5.098 .656 .139 & 2.290 .700 .584 & 7.389 .356 .723 & 4672 & 5.396 .905 .134 & 2.424 .696 .510 & 7.821 .601 .644 & 3.886 & 4.533 .400 .313 & 2.036 .745 .068 & 6.570 .145 .381 \\
\hline BPJS Kesehatan & 16568 & 3.983.982.883 & 804.458 .082 & 4.788 .440 .965 & 16023 & 2.981.874.986 & 602.109 .372 & 3.583.984.358 & 14.140 & 3.995.712.481 & 806.826 .559 & 4.802 .539 .040 \\
\hline Total Piutang & 106.289 & 19.448 .250 .272 & 8.845 .123 .154 & 28.293.373.426 & 102.794 & 15.014.222.923 & 6.770 .393 .953 & 21.784.616.876 & 108.416 & 15.990 .652 .442 & 7.078.402.823 & 23.069.055.265 \\
\hline
\end{tabular}

Sumber: RSUD Sekayu Kabupaten Musi Banyuasin, 2018, data diolah 
Jurnal Ilmiah Akuntansi Rahmaniyah (JIAR)

Vol. 3 No.1, Desember 2019, 50-67

Tabel 5

Ermawijaya

Analisa Umur Piutang dan Estimasi Piutang Tak Tertagih

RSUD Sekayu Kabupaten Musi Banyuasin

Tahun 2016-2018

(Dalam Rupiah)

\begin{tabular}{|c|c|c|c|c|c|c|}
\hline \multirow{2}{*}{ Tahun } & \multicolumn{6}{|c|}{ Umur Piutang } \\
\cline { 2 - 7 } & 0-12 Bulan & $1-2$ Tahun & 2-3 Tahun & 3-5 Tahun & $>$ 5 Tahun & Jumlah \\
\hline 2016 & 11.292 .685 .382 & 5.658 .674 .685 & 7.073 .343 .357 & 1.499 .548 .792 & 2.769 .121 .211 & 28.293 .373 .426 \\
\hline 2017 & 8.925 .422 .506 & 5.446 .154 .219 & 3.267 .692 .531 & 1.481 .353 .948 & 2.663 .993 .672 & 21.784 .616 .876 \\
\hline 2018 & 9.514 .015 .176 & 5.767 .263 .816 & 3.460 .358 .290 & 1.684 .041 .034 & 2.643 .376 .948 & 23.069 .055 .264 \\
\hline $\begin{array}{c}\text { Persentase piutang } \\
\text { tidak tertagih (\%) }\end{array}$ & $0 \%$ & $25 \%$ & $50 \%$ & $75 \%$ & $100 \%$ & - \\
\hline 2016 & - & 1.414 .668 .671 & 3.536 .671 .678 & 1.124 .661 .594 & 2.769 .121 .211 & 8.845 .123 .154 \\
\hline 2017 & - & 1.361 .538 .555 & 1.633 .846 .266 & 1.111 .015 .461 & 2.663 .993 .672 & 6.770 .393 .953 \\
\hline 2018 & - & 1.441 .815 .954 & 1.730 .179 .145 & 1.263 .030 .776 & 2.643 .376 .948 & 7.078 .402 .823 \\
\hline
\end{tabular}

Sumber: RSUD Sekayu Kabupaten Musi Banyuasin, 2018, perhitungan berdasarkan peraturan gubernur nomor 9 tahun 2014. 
Berdasarkan tabel 4 dan 5 di atas, menunjukkan bahwa jumlah piutang tak tertagi pada RSUD Sekayu dari Tahun 2016 sampai dengan 2018 mengalami fluktuasi. Pada tahun 2016 piutang tak tertagih sebesar Rp. 8.845.123.154, mengalami penurunan tahun 2017 dengan jumlah piutang tak tertagih sebesar Rp. 6.770.393.953 dan pada Tahun 2018 mengalami peningkatan dengan jumlah piutang tak tertagih sebesar Rp. 7.078.402.823. Jumlah ini akan berdampak pada pendapatan RSUD Sekayu. Jika jumlah piutang tak tertagih dikurangkan dalam setiap tahun makaakan mengakibatkan RSUD Sekayu mengalami defisit yang cukup signifikan dan jika diestiamsi secara berangsur pengurangan piutang tak tertagih berdasarkan kebijakan RSUD maka pendapatan akan minimal tetapi tidak berakibat defisit yang besar dan jumlah pendapatan yang kecil.

\subsection{Dampak piutang tak tertagih terhadap Pendapatan RSUD Sekayu}

Jika dilihat dari tabel 2 yaitu perolehan pendapatan RSUD Sekayu, sangat tidak memungkinkan untuk dihapus dari laporan keuangan karena surplus yang diperoleh tidakkan mencukupi. Berdasarkan hasil analisa penulis pada RSUD Sekayu diketahui bahwa besarnya jumlah piutang tak tertagih ini sebagai akibat kebijakan manajemen RSUD Sekayu yang tidak bersedia menghapuskanpiutang tak tertagih karena akan berakibat berkurangnya surplus pendapatan dan berdampak pada kurang baiknya kinerja manajemen. Selain itu, manajemen beranggapan piutang tak tertagih ini bukan akibat kebijakannya, tetapi disebabkan

a. Manajemenpuncak RSUD Sekayu menanggung biaya politik berupa "Berobat Gratis"yang dicanangkan pemerintah daerah.

b. Biaya yang harus dikeluarkan untuk menagih piutang kepada pasien yang menunggak tersebar di seluruh wilayah Kabupaten Musi Banyuasin lebih banyak daripada nilai piutangnya yang tertunggak, sehingga besarlah biaya penangihan daripada pokok piutang yang tak tertagih.

Sebagai akibat tidak tertagihnya piutang tersebut dari tahun ke tahun maka jumlah piutang yang tertagih semakin menumpuk/banyak, sehingga apabila dihapuskan pada satu tahun, manajemen dalam tahun tersebut keberatan karena kinerja manajemen RSUD Sekayu saat itu dianggap kurang baik karena tidak menghasilkan surplus pendapatan yang banyak. 
Manajemen yang bersangkutan keberatan melakukan penghapusan piutang karena manajemen RSUD Sekayu selalu berganti-ganti atau mutasi disesuaikan dengan peraturan pemerintah daerah, apalagi pimpinan tertinggi Kabupaten Musi Banyuasin yang mengangkat manajemen RSUD selalu berubah setiap 5 tahun sekali.

Dampak dari kebijakan manajemen RSUD dalam menerapkan metode penghapusan piutang tak tertagih dengan menggunakan metode cadangan/penghapusan tidak langsung adalah penyajian piutang di Neraca tidak menggambarkan kondisi keuangan yang sebenarnya.

\section{SIMPULAN}

Berdasarkan pembahasan penerapan metode penghapusan piutang tak tertagih terhadap pendapatan RSUD Sekayu, maka dapat disimpulkan bahwa :

1. Metode penghapusan piutang yang tak tertagih yang diterapkan oleh RSUD Sekayu adalah metode pengahapusan tidak langsung/cadangan. Dampak yang dimbulkan dari penerapan metode ini adalah bahwa nilai piutang yang disajikan di Neraca bukan menggambarkan nilai yang sebenarnya.

2. Dampak penerapan metode penghapusan piutang dengan tidak langsung/cadangan terhadap pendapatan adalah nilai piutang tak tertagih cukup besar dan akan mengurangi pendapatan RSUD Sekayu dan mempengaruhi surplus pendapatan yang di peroleh

Manajemen RSUD Sekayu diharapkan dapat melakukan penghapusan piutang yang tidak dapat direalisasikanpembayarannya secara bertahap, sehingga berdasarkan ketentuan akuntansi dan keinginan manajemen RSUD Sekayu dapat tercapai secara bersama.

\section{DAFTAR PUSTAKA}

Abdul, Halim. 2012. Akuntansi Sektor Publik Keuangan Daerah. Jakarta: Salemba Empat.

Atmaja, Lukas Setia. 2012. Manajemen Keuangan. Yogyakarta: Andi.

Al Haryono, Jusup. 2014. Dasar-Dasar Akuntansi. Jilid dua. STIE YKPN. Yogyakarta.

Horne, James, C. dan Jhon, M. Wachowicz. 2012. Prinsip-Prinsip Manajemen Keuangan. Yogyakarta: Salemba Empat. 
Ikatan Akuntansi Indonesia. 2009. Standar Akuntansi Keuangan: PSAK Nomor 1 Penyajian laporan keuangan.Jakarta: Salemba Empat

Setiawan, Iwan. 2010. Akuntansi Keuangan Menengah (Intermediate Accounting). Bandung: Refika Aditama.

Sugiyono. 2010. Metode Penelitian Kuantitatif Kualitatif dan R\&D. Alafabeta: Bandung.

Warren, Reeve, dan Fees yang diterjemahkan oleh Farahmita, Amanaugrahani, Hendrawan, T. 2008. Pengantar Akuntansi. Jakarta: Salemba Empat

Wibowo, Ady. Manajemen Piutang.

http://adywibowo.wordpress.com/2011/11/27/manajemen-piutang-2/. 